\title{
Boris Jeltsin. Reformatorn som inte nådde ända fram
}

\author{
Stig Fredrikson 2016 \\ Stockholm: Carlsson Bokförlag \\ 319 sider. ISBN: 9789173317764
}

Omtalt av Gro Holm (utenriksjournalist, tidligere korrespondent i Russland, Norsk Rikskringkasting, gro.holm@nrk.no)

Allerede i forordet tilkjennegir forfatteren hva som er hans prosjekt: «I dag när Ryssland under Putin har återgått till ett styre som får allt tydligare sovjetiska drag, är det dags at återupprätta Boris Jelstin» (s. 10). Han mener at Jeltsins drivkraft var et oppriktig ønske om «att gjöra livet bettre för sina ryska landsmän» (s. 309). Et annet hovedpoeng i boka er at «begreppet frihet var mycket viktigare för Jeltsin än begreppet demokrati» (s. 300). Som det går fram av tittelen, så nådde han ikke helt fram.

Fredrikson baserer seg for en stor del på Jeltsins tre memoarbøker, biografier og intervju med tidligere medarbeidere av Jeltsin. Dessuten bruker den mangeårige utenriksjournalisten egne manus, skrevet som korrespondent og kommentator for SVT.

Mye av boka handler om tiden før Sovjetunionens oppløsning 25. desember 1991, da Mikhail Gorbatsjov gikk av som Sovjetunionens president og Boris Jeltsin som Russlands president ble ubestridt leder i etterfølgerstaten. Mens Vesten hadde trykket Gorbatsjov til sitt hjerte, var det mange som var usikre på Boris Jeltsin. Paradoksalt nok foretrakk mange instinktivt mannen som ville reformere sovjetsystemet gradvis framfor han som forbød Kommunistpartiet (s. 101).

For å forklare hvorfor Jeltsin gikk inn for mer omfattende og raskere reformer enn Gorbatsjov, går forfatteren helt tilbake til ulikheter i familienes historier. Mens Gorbatsjovs morfar slapp med ett år i fengsel under Stalin, ble Jeltsins far sendt på hardt straffarbeid $\mathrm{i}$ tre år for å ha «saboterat det socialistiska samhällsbygget bl.a. genom att klaga på maten på arbetsplatsen» (s. 26). Jeltsin ble medlem av Kommunistpartiet i 1961, men han ble aldri glødende kommunist, og et av hans hovedmål som president ble å forhindre at kommunistene igjen fikk komme til makten.

I flere årtier gikk Jeltsins karriere innenfor det sovjetiske systemet jevnt og trutt framover, fra han ble uteksaminert som bygningsingeniør ved Urals tekniske høyskole 
i 1955, via jobben som partisjef i Sverdlovsk fylke, til den svært viktige jobben som partisjef i Moskva. Allerede i Sverdlovsk ble han kjent for sine direkte møter med folket. Det hadde knapt skjedd før at borgerne kunne stille så kritiske spørsmål til en partileder uten å risikere straff. Men Jeltsin lyttet til folks klager og så det som sin hovedoppgave å sikre befolkningen mat og bedre boliger.

Som partisjef i Moskva ble han sjokkert over korrupsjonen, ikke minst den som var institusjonalisert i form av privilegier for medlemmer av det sentrale partiapparatet. Jeltsin ville renske opp. Han avsatte eller flyttet på 23 av 33 lokale partisjefer i Moskva i løpet av sitt første år, og han kritiserte åpent Gorbatsjov.

Det første store oppgjøret mellom de to kom på et møte i partiets sentralkomité i oktober 1987. Jeltsin holdt en tale der han anklaget Gorbatsjov for å være for forsiktig og beskyldte ham for å fremme en ja-kultur der ingen torde annet enn å lovprise generalsekretæren. Han mistet jobben som partisjef i Moskva. Gorbatsjov sa at «in i politiken släpper jag dig aldrig mer» (s. 81).

Men Boris Jeltsin fikk hevn, dels takket være reformer Gorbatsjov stod i bresjen for. Gorbatsjov forsøkte hele tiden å balansere mellom reformmotstanderne og de liberale i Kommunistpartiet. For å skaffe seg et maktgrunnlag som var uavhengig av partiet, gikk han inn for å opprette en ny folkevalgt forsamling, Kongressen av folkedeputerte, som igjen valgte et parlament, Det øverste sovjet. Gorbatsjov ble parlamentsformann og fikk tittelen «president» i Sovjetunionen. Samtidig sørget han for å avskaffe Kommunistpartiets maktmonopol.

Året etter, i 1990, ble det holdt parlamentsvalg i de 15 unionsrepublikkene, og Jeltsin ble president i Russland. I juni 1991 ble han så valgt til president i den russiske sovjetrepublikken i direkte valg. Jeltsin støttet også de andre sovjetrepublikkenes uavhengighet, i den grad at han oppfordret sovjetiske soldater i Baltikum til ikke å adlyde ordre om de ble bedt om å slå ned demonstranter som ønsket løsrivelse. For Fredrikson er dette et tegn på «Jeltsins storhet» (s. 295).

$\mathrm{Da}$ en mektig gruppe konservative kommunister forsøke seg med statskupp mens Gorbatsjov var på ferie i august 1991, var det Jeltsin som tok ledelsen og ble Gorbatsjovs redningsmann. Gorbatsjov forsøkte desperat å få til en unionsavtale med noen av sovjetrepublikkene. Men da Jeltsin gikk bak ryggen på den sovjetiske presidenten og inngikk avtale med Hviterussland og Ukraina 8. desember om å danne «Samveldet av uavhengige stater», var Sovjetunionen i realiteten oppløst.

Fredrikson beskriver disse begivenhetene uten å ta opp spørsmålet mange har stilt, nemlig om Sovjetunionen kunne eksistert videre om ikke en hadde hatt maktkampen mellom Jeltsin og Gorbatsjov.

Derimot beskriver han hvordan president Jeltsin selv trodde på og forsvarte den økonomiske sjokkterapien, der frislipp av priser og privatisering av gigantiske foretak basert på Russlands naturressurser var sentrale elementer. Hyperinflasjon og matmangel fulgte, og i 1993 hadde det russiske parlamentet utviklet seg til et alternativt maktsentrum og Jeltsins farligste motstander. Presidenten avgjorde maktkampen ved å sette inn stridsvogner og soldater mot Det hvite hus (parlamentet). 
187 mennesker ble drept, men Jeltsin mente det var helt nødvendig for å forsvare demokratiet og angret aldri, skriver Fredrikson.

Forfatteren problematiserer heller ikke Jeltsins vurdering. Men han reiser et svært viktig spørsmål uten å gi noe egentlig svar, nemlig om denne og andre kriser kunne vært unngått dersom Jeltsin hadde stilt seg i spissen for et parti som kunne vært hans allierte i parlamentet, Dumaen.

Jeltsin mente også det var helt nødvendig å slå ned separatistene i Tsjetsjenia, men krigen fra desember 1994 kostet ham støtten fra mange i den demokratiske leiren. Mediene dekket krisene uten filter, og giennom hele sin presidentperiode holdt han fast ved at tale- og trykkefriheten var ukrenkelig. Det gjaldt også når mediene rapporterte om pinlige episoder med en synlig beruset president $i$ utlandet.

Sterkt preget av hjerteproblemer var han opptatt av å finne en etterfølger med stor arbeidskapasitet, som var disiplinert og uten følelsesutbrudd. Valget falt på avholdsmannen Vladimir Putin, som hadde lovet å fortsette demokratiseringsprosessen. Men Jeltsin hadde selv sørget for å etablere en sterk presidentmakt, uten å bygge opp stabile samfunnsinstitusjoner som kunne stå imot, påpeker Fredrikson. Det skulle Putin komme til å utnytte.

Boka er en lettlest historie om en av hovedaktørene i fortellingen om det russiske/sovjetiske imperiets oppløsning. Noen vil nok savne kildehenvisninger utover Jeltsins memoarer og noen få til. Men det ville vært en annen slags bok. 